\title{
Concurrent metastatic hepatoid gland carcinoma and eosophagogastric leiomyosarcoma in a dog
}

\author{
Arda Selin TUNC, Mehmet Eray ALCIGIR, Sevil ATALAY VURAL \\ Department of Pathology, Faculty of Veterinary Medicine, Ankara University, Ankara
}

\begin{abstract}
Summary: A 17-year-old male, mongrel dog was evaluated for a primary mass localized between perianal and sacral region and metastatic foci on lung. It was also encountered coincidentally with another mass taking place between distal esophagus and cardia of stomach and metastatic foci in kidney. In histopathological examination, perianal localization of mass and metastatic foci on lung were diagnosed as hepatoid gland carcinoma while esophagogastric mass and metastatic foci in kidney were diagnosed as leiomyosarcoma. In immunohistochemical examination, Ki-67 marker gave positive reaction in nuclei of anaplastic hepatoid gland cells in spite of vimentin and $\alpha$-smooth actin positivity were found in reserve cells of the tumor. But, there was only positive with actin marker in leiomyosarcoma. It is considered useful to share results of the two different concurrent tumor in same dog.
\end{abstract}

Key words: Dog, hepatoid gland carcinoma, leiomyosarcoma.

\section{Bir köpekte eş zamanlı metastatik hepatoid bez karsinomu ve özofagogastrik leiomyosarkom}

Özet: 17 yaşlı erkek bir köpekte perianal ve sakral bölge arasında lokalize olan primer bir kitle ile akciğerdeki metastatik odaklar değerlendirildi. Rastlantısal olarak distal özefagus ve midenin kardiyası arasında yer alan diğer bir kitleyle birlikte böbrekte benzer odaklara rastlandı. Histopatolojik incelemede özefagogastrik yerleşimli ve böbrekte bulunan kitlelerin leiomyosarkom olarak tanılandırılmasına karşın, perianal bölgedeki kitle ile akciğerdeki metastatik odaklar hepatoid bez karsinomu olarak tanılandırıldı. İmmunohistokimyasal incelemede, vimentin ve $\alpha$-smooth actin tümör rezerv hücrelerinde pozitif bulunmasına rağmen, Ki67 anaplastik hepatoid bez hücrelerinde pozitif reaksiyon verdi. Fakat leiomyosarkom sadece $\alpha$-smooth actin ile pozitifti. Aynı köpekte iki farklı tümöre rastlanması açısından sonuçların paylaşılmasının yararlı olduğu düşünüldü.

Anahtar sözcükler: Hepatoid bez karsinomu, köpek, leiomyosarkom.

\section{Introduction}

Hepatoid gland carcinoma (HGC) is responsible for $3-17 \%$ of all perianal sourced neoplasms $(5,28)$. It is more common in intact male dogs than females (27). HGC is usually seen in 4-15 year-old dogs (8). Developing of the tumor depends on androgenic effect $(5,17)$. The malignant tumors can be multiple or primarily invasive into underlying tissue. Metastasis generally occurs to regional (iliac and abdominal) lymph nodes, liver, kidney, bones and lungs $(7,18,25,27)$. There is race predisposition in Cocker spaniel, Beagle, Siberian Huskies, Alaskan Malamutes and Bulldogs (7, $18,25,28)$. Smooth muscle tumor is rarely documented in esophagus and stomach when compared to intestine. Because the tumor is generally found in gastroesophageal junction, it is evaluated with together as regard leiomyoma (LM) and leiomyosarcoma (LMS) (11). LMS is usually encountered over approximately 7 year-old dogs and has no breed and sex predisposition (21). LMS is a slowly developing and locally invasive malignant tumor. The metastasis of LMS occurs in mesenteric lymph nodes, peritoneum, liver and spleen $(1-3,15)$. In alimentary system, leiomyomas are more common in stomach, leiomyosarcomas are more seen in intestine (21). The case has been found very attractive with regard to encountering with two types of tumor and their metastasis in the same dog. It is aimed to show that different tumors can be occured and seen their metastasis in older animals.

\section{Materials and Methods}

A 17 year-old, male, mongrel dog was dead after with complaints of lethargy and anorexia. Necropsy was performed and tissue samples were collected. They were fixed in $10 \%$ buffered formalin, processed routinly and embedded in parafin. Tissues were sectioned at $5 \mu \mathrm{m}$ thickness and stained with haematoxylin-eosin (H\&E) and Masson's trichrome (MTC) stains. Immunohistochemically, deparaffinization and dehydration were provided and peroxidase activity was removed from the 
tissues on adhesived slides with $3 \%$ hydrogen peroxidemethanol solution. Nonspesific proteins in tissue were blocked by using protein blocking solution. Primary antibodies were selected as anti-alpha smooth actin (1:200 dilution, clone 1A4, Sigma), anti-vimentin (1:100 dilution, clone vim3B4, Dako), anti-Ki67 (1:800 dilution, clone PP-67). Streptavidin biotin complex (Strept ABC) peroxidase method was applicated on all sections by using Strept ABC peroxidase kit (Novocastra Peroxidase Detection Systems). As chromagen, 3,3diaminobenzidine (DAB) was used and counterstaining was stained by Harris's haematoxylin. For negative controls, normal goat sera was used instead of each primary antibodies. Procedures except this stage were the same. All microscopical areas were evaluated and positivities were picked up from 10 areas at same magnification. They were scored as slight, mild and moderate as $<10 \%, 10-50 \%,>50 \%$ respectively.

\section{Results}

Macroscopical Findings: The first mass was located between perianal region and sacrum. The HGC mass was diametered in 7x8x6 $\mathrm{cm}$ and had grayishwhite color and elastic consistency with lobular appearance at the cross section (Figure 1). After necropsy was performed, another mass lying from the distal esophagus to cardia region of the stomach was found and examined. It was diametered in $6 \times 6 \times 7 \mathrm{~cm}$. The mass had a grayish-white colored cut section and elastic consistency (Figure 2). In addition, there were metastatic foci on left kidney's cortex, 1-3 $\mathrm{mm}$ in diameter and grayish-whitish color (Figure 3). Also there were observed masses on lungs, especially left and right cranial lobes, 5-20 $\mathrm{mm}$ in diameter, elastic consistency and grayish-white appearance on cut section (Figure 4).

Histopathological Findings: The mass, which spread from perianal region to sacrum, was composed of

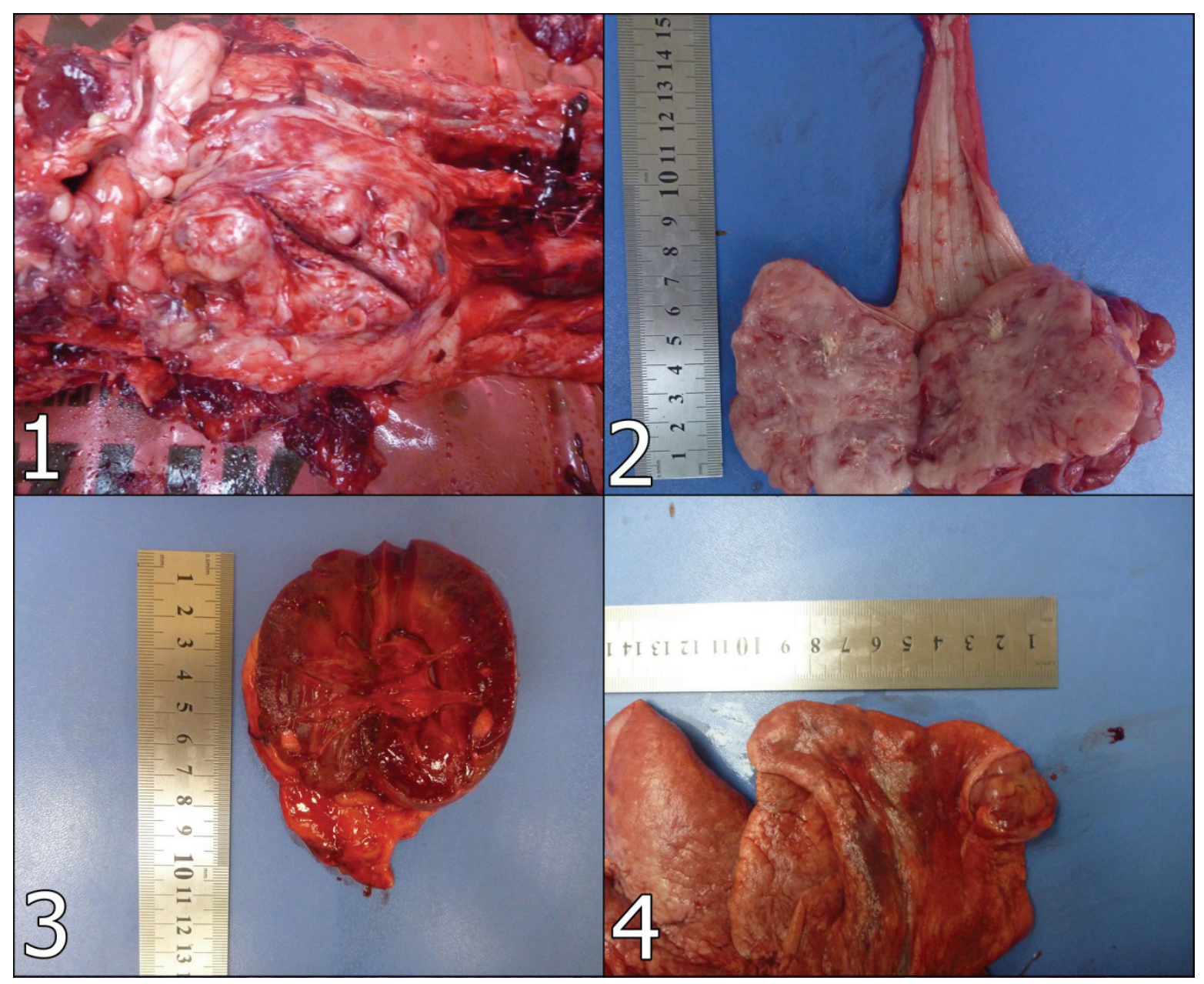

Figure 1: HGC mass located between perianal region and sacrum.

Şekil 1: Perianal bölge ve sakrum arasında lokalize olan HGC kitlesi.

Figure 2: LMS mass lying from the distal esophagus to cardia region of the stomach.

Şekil 2: Distal özefagustan midenin kardiyasına kadar yayılan LMS kitlesi.

Figure 3: Gross appearance of metastatic foci on left kidney's cortex.

Şekil 3. Sol böbrek korteksinde metastatik odakların makroskobik görünümü.

Figure 4: Gross appearance of metastatic masses on lungs

Şekil 4: Akciğerlerdeki metastatik kitlelerin makroskobik görünümü. 


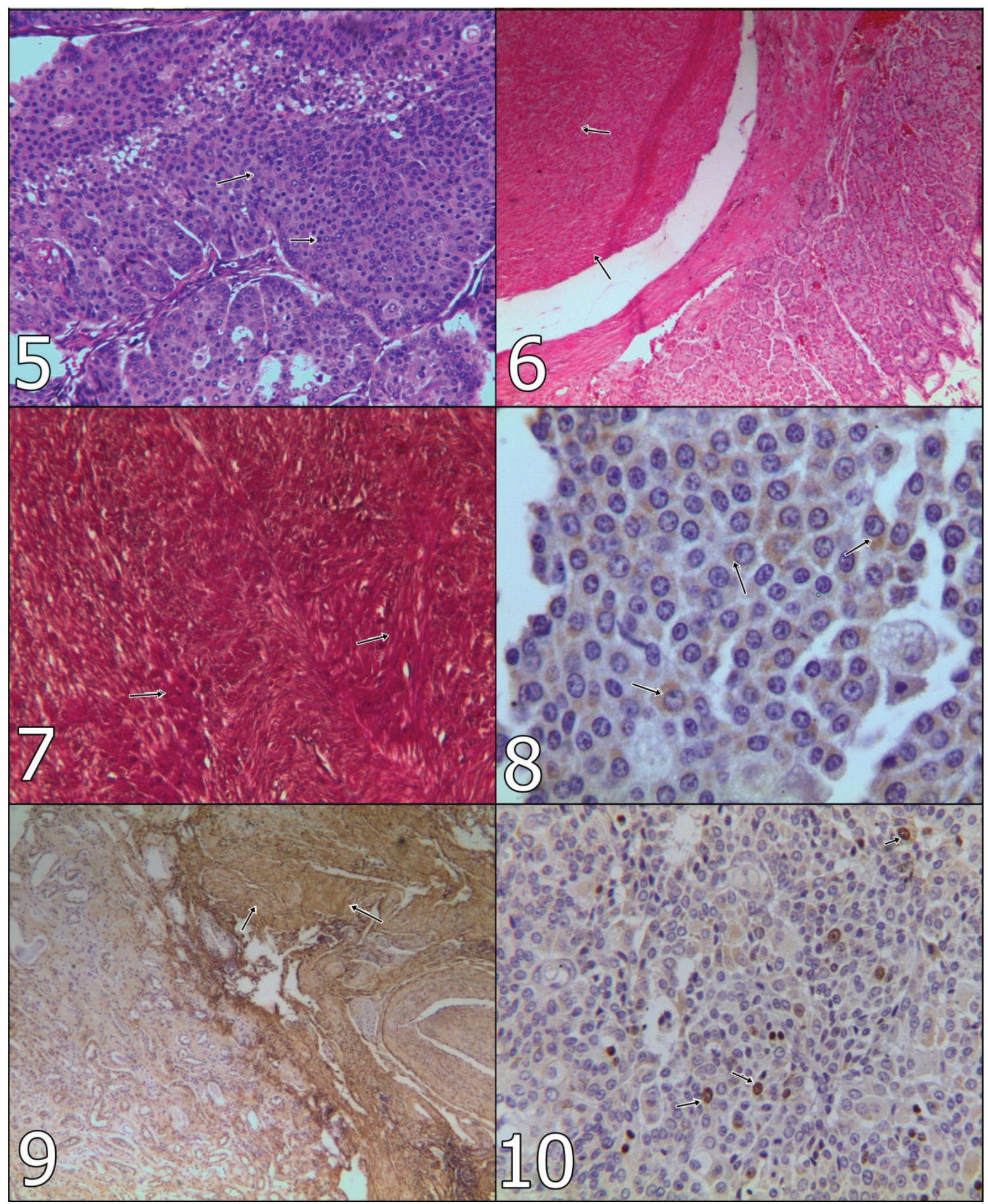

Figure 5: Anaplastic perianal gland cells (arrows), x100, H\&E. Şekil 5: Anaplastik perianal bez hücreleri (oklar), x100, H\&E.

Figure 6: Neoplastic smooth muscle cells (arrows), x100, H\&E. Şekil 6: Neoplastik düz kas hücreleri (oklar), x100, H\&E.

Figure 7: Differentiation of smooth muscle cells from connective tissue (arrows) x100, Masson's trichrome stain. Şekil 7: Düz kas hücrelerinin bağ dokusundan ayrımı (oklar), x100, Masson'un trikrom boyaması.

Figure 8: Actin positivity in HGC in primary mass (arrows), x400, ABC-P.

Şekil 8: HGC'de primer odakta aktin pozitifliği (oklar), x400, ABC-P.

Figure 9: Actin positivity in LMS in kidney (arrows), x100, ABC-P.

Şekil 9: Böbrekte LMS'de aktin pozitifliği (oklar), x100, ABC-P.

Figure 10: Ki67 positivity in HGC on lung (arrows), x400, ABC-P. Şekil 10: HGC'de akciğerde Ki67 pozitifliği (oklar), x400, ABC-P. 
polyhedral shape cells like hepatocyte, anaplastic perianal gland cells with generally oval to round shape nuclei. They had frequently abundant cytoplasm, but there were hypochromatic nuclei and/or hyperchromatic nuclei and prominent nucleoli in high preporendence (Figure 5). A few mitotic figures were seen in microscopical areas. On the lung were noticed metastatic foci of the tumor. The mass, in the esophagus and stomach, characterized in different directions, shuttle or oval-shaped, in places, showing mitotic figures, hypochromatic nucleus and narrow eosinophilic cytoplasm was encountered in neoplastic smooth muscle cells (Figure 6). Masses in the kidney were noticed metastatic foci of leiomyosarcoma. In MTC, smooth muscle cells were differentiated from connective tissue (Figure 7).

Immunohistochemical Findings: Actin antibody was positive in both HGC and LMS (Figures 8-9). On the other hand, Ki-67 and vimentin antibodies gave positive reaction in nuclei of $\mathrm{HGC}$ cells (Figure 10), although they were negative in LMS.

\section{Discussion}

HGC is a cancer which originated from a sebaceous type gland localizated mainly anal orifice, perineum, tail and lumbosacral region (22). It is rarely seen than benign counterpart and can sometimes metastasize to different internal organs such as regional lymph nodes, liver, kidney, bones and lungs (27). In the case metastasis sites are generally accorded to knowledges excepting regional lymph nodes.

HGC is generally occured between 8-12 years of age. Most affected breeds are Siberian Husky, Shih Tzu and mixed ones. It is seen more frequently in male than female $(7,27)$. For LMS, it is stated that 7 years of age is most common affective age between dogs if the tumors is localizated at alimentary system as predilection sites. However, it is not mentioned any breed and sex predisposition $(15,21)$. In current case, neoplastic changes were seen in a 17-year-old mongrel dog. It is understood that the case was out of range of age. But, it is commented more predisposed to HGC because of being male and mixed breed.

The HGC tumor is macroscopically seen as yellowish-white color. It has multilobullary appearence and also sometimes ulceration and haemorrhagia. The appearence can not be distinguished from benign counterpart in terms of mass localization and main macroscopical features (8). In the case, the mass was grayish-white and approximately $7 \mathrm{~cm}$ in diameter. There were masses which had in same appearence vary from 5 to $20 \mathrm{~mm}$ in diameter on lungs. Histopathologically, there were lobules and sheets composed of polygonal shape cells which had undifferentiated hyperchromatic nuclei, prominent nucleoli and abundant eosinophilic cytoplasms. Reserve cells which were at peripheral localization of hepatoid gland cells could sometimes show nuclear pleomorphism and mitotic figures (7). In the case, appearence of the anaplastic cells were parallel to that of literatures. But, there were no nuclear pleomorphism in spite of being quite a few mitotic figures in both primary mass and metastatic foci.

It is difficult to describe and diagnose as leiomyosarcomas because malignancy criteria do not show properly in consideration (11). Tumor size could vary from 0.5 to $24 \mathrm{~cm}$ in diameter have round or oval shape and thin capsule. Its cut surface is homogenated and pink tan. The mass causes dilatation in eosophagus due to localization, regurgitation of food and gastric tension $(10,24)$.

Immunohistochemically, the studies generally focused on integral membran tight junction (12-14), tumor cell-hormon dependency mechanism (22). There are also some studies about making its differentiation from other tumors by using several antibodies. Furthermore, perianal gland tumor is stained with keratin, vimentin, neuroflament protein, smooth muscle actin, neuron spesific enolase (NSE) and synaptophysin, mAbs 4A9 and 1A10 antibodies (29). Especially, keratin is found beneficial for identification of epithelial source. A-smooth actin and NSE are useful to detect the basally located cells or reserve cells which are possibly myoepithelial source despite of no reaction in carcinoma cells. It was not encountered any studies in evaluation of the subject with malignancy by using Ki67. It was found usefully for evaluation nuclear activity in transformation to malignancy of perianal glands. However, it was not obtained any positive results from leiomyosarcomas. In this context, it is more reliable to use in epithelial origin tumors. On the other hand, there are restricted immunohistochemical studies canine leiomyosarcoma localizated in alimentary system. Leiomyosarcoma gives positive reaction with $\alpha$-smooth actin, desmin, vimentin and S-100 antibodies $(6,16)$. Moreover, AgNOR and Ki67 are found positive in LMS (6). However, it could not be obtained positive reaction with markers excepting out alpha smooth actin antibody. In this context, immunohistochemistry was revealed it out detail results than special stain as regard detection of the tumors which source they are. The tissue gave positivity with alpha smooth actin antibodies. The diagnosis was also confirmed in metastatic foci in other sites by positive reaction.

According to the literatures, there are no reports on these concurrent tumors. It is quite a few about two different type of tumor together. It is generally observed on human or animal reports for alimentary system leiomyosarcoma. Two reports informed on esophageal 
leiomyosarcoma and squamous carcinoma were together in spite of that one report mentioned gastric leiomyosarcoma and adenocarcinoma (4, 6, 19, 23, 26). However, these tumors can be made an inference that it has same etiology due to the exposure of same carcinogens or genetic mutation because they are occured in the same organ. About HGC, it is only described to perianal gland adenoma concurrent with prostatic hyperplasia in a dog (20). It can be commented tumor growing under the hormonal effect. On the other side, some factors play role on the development of cancer in older ones. One factor is closely related to exposure to carcinogens as cumulative through their life. There is another factor that alterations in the immune or hormonal mechanisms, which allows to these kind of neoplastic changes. And also, it is taken place a susceptibility to neoplastic transformation in cells (9). In present case, possible happening of conincidental HGC and leiomyosarcoma were also commented in this direction. When excepting this case, there is no information on concurrent tumors.

In conclusion, it is described pathomorphologically and immunohistochemically an original case which have two different origin tumors. It is found to be worth sharing results due rarely occurence.

\section{References}

1. Bruecker KA, Withrow SJ (1988): Intestinal leiomyosarcoma in six dogs. J Am Anim Hosp Assoc, 24, 281-284.

2. Cohen M, Post GS, Wright JC (2003): Gastrointestinal leiomyosarcoma in 14 dogs. J Vet Intern Med, 17, 107110.

3. Crawshaw J, Berg J, Sardinas JC, Engler SJ, Rand WM, Ogilvie GK, Spodnick GJ, Petterino C, Martini M, Castagnaro M (2004): Immunohistochemical detection of growth $(G H)$ in canine hepatoid gland tumors. J Vet Med Sci, 66, 569-572.

4. Farese JP, Bacon JP, Ehrhart NP, Bush J, Ehrhart EJ, Withrow SJ (2008): Oesophageal leiomyosarcoma in dogs: surgical management and clinical outcome of four cases. Vet Comp Oncol, 6, 31-38.

5. Genevois JP (1980): Pathologie ano-rectale et perineale. I Circumnalomes. Rev Med Vet, 131, 697-705.

6. Gillespie V, Baer K, Farelly J, Craft D, Luong $\mathbf{R}$ (2011): Canine Gastrointestinal Stromal Tumors: Immunohistochemical Expression of CD34 and Examination of Prognostic Indicatorts Including Proliferation Markers Ki67 and AgNOR. Vet Pathol, 48, 283.

7. Ginn PE, Mansell JEKL, Rakich PM (2007): Skin and appendages. 756-757. In: Maxie MG. Jubb, Kennedy and Palmer's Pathology of Domestic Animals. Chapter 5. 5th ed., vol 1, Saunders Elsevier, Philadelphia-USA.

8. Goldschmidt MH, Hendrick MJ (2002): Tumors of the Skin and Soft Tissues. 68-70. In Meuten DJ. Tumors in Domestic Animals, Chapter 2, 4th edition. Iowa state pres Ames, IA, USA.
9. Grubeck-Loebenstein B, Wick G (2002): The aging of the immune system. Adv Immunol, 80, 243-84.

10. Hayden DW, Nielsen SW (1973): Canine alimentary neoplasia. Zbl Vet Med, 20A, 1-22.

11. Head KW, Else RW, Dubielzig RR (2002): Tumors of the Alimentary Tract. 440-441, 458-459. In: Meuten DJ (Ed). Tumors in Domestic Animals, 4th ed. Iowa state pres, Ames, IA, USA.

12. Jakab C, Rusvai M, Galfi P, Kulka J (2010): Expression of claudin-7 molecule in canine perianal gland tumours. Acta Vet Brno, 79, 127-133.

13. Jakab C, Rusvai M, Galfi P, Mandoki M, Demeter Z, Szabo Z, Kulka J (2010): Expression of claudin-5 in hepatoid gland biopsies. Vet Dermatol, 21, 276-281.

14. Jakab C, Rusvai M, Szabo Z, Szabara A, Kulka J (2009): Expression of the claudin-4 molecule in benign and malignant canine hepatoid gland tumours. Acta Vet Hung, 57, 463-475.

15. Kapatkin AS, Mullen HS, Mathiesen DT, Patnaik AK (1992): Leiomyosarcoma in dogs: 44 cases (1983-1988). J Am Vet Med Assoc, 201, 1077-1079.

16. LaRock RG, Ginn PE (1997): Immunohistochemical Staining Characteristic of Canine Gastrointestinal Stromal Tumors. Vet Pathol, 34, 303-311.

17. Maita K, Ishida K (1975): Structure and development of the perianal gland of the dog. Jpn J Vet Sci, 37, 349-356.

18. Müller GH, Kirk RW, Scott DW (1983): Perianal Gland Tumors. 736-738. In Small Animals Dermatology. 3rd ed., Saunder Co, Philadelphia.

19. Ovens JM, Russel WO (1951): Concurrent leiomyosarcoma and squamous carcinoma of the esophagus. AMA Arch Pathol, 51, 560-564.

20. Park C, Yoo JH, Kim HJ, Lim CY, Kim JW, Lee SY, Kim JH, Jang JI, Park, HM (2010): Cyclosporine treatment of perianal gland adenoma concurrent with benign prostatic hyperplasia in a dog. Can Vet J, 51, 1279-1282.

21. Patnaik AK, Hurvitz AI, Johnson GF (1977): Canine Gastrointestinal Neoplasms. Vet Pathol, 14, 547-555.

22. Pisani G, Millanta F, Lorenzi D, Vannozzi I, Poli A (2006): Androgen receptor expression in normal, hyperplastic and neoplastic hepatoid glands in the dog. Res Vet Sci, 81, 231-236.

23. Rella AJ, Farrell JT, Comer JV (1965): Concurrent leiomyosarcoma and squamous cell carcinoma of esophagus. N Y State J Med, 15, 1254-1256.

24. Rolfe DS, Twedt DC, Seim HB (1994): Chronic regurgitation or vomiting caused esophagal leiomyoma in three dogs. J Amer Anim Hosp Assoc, 30, 425-430.

25. Stannard AA, Pulley LT (1978): Perianal Gland Tumors. 59-62. In: Moulton JE. Tumors in Domestic Animals, 2nd ed., University of California Press. Ltd. London-England.

26. Swan HW, Hol DE (2002): Canine Gastric Adenocarcinoma and Leiomyosarcoma: A retrospective study of 21 cases (1986-1999) and literature review. J Am Anim Hosp Assoc, 38, 157-164.

27. The Merck Veterinary Manual (2011): Hepatoid Gland Tumors (Perianal gland tumors, circumanal gland tumors. Online access: http://www.merckvetmanual.com/mvm/index.jsp?cfile=htm/ bc/72212.htm, Access date: 19.12.2012. 
28. Vail DM, Withrow SJ, Schwarz PD, Powers BE (1990): Perianal adenocarcinomas in the canine male: a retrospective study of 41 cases. J Am Anim Hosp Assoc, 26, 329-334.

29. Vos JH, van den Ingh TS, Ramaekers FC, Molenbeek RF, de Neijs M, van Mil FN, Ivanyi D (1993): The expression of keratins, vimentin, neurofilament proteins, smooth muscle actin, neuron-specific enolase, and synaptophysin in tumors of the specific glands in the canine anal region. Vet Pathol, 30, 352-361.
Geliş tarihi: 04.07.2013 / Kabul tarihi: 04.10.2013

\section{Address for correspondence;}

Res.Assist. Arda Selin Tunc

Ankara University,

Faculty of Veterinary Medicine,

Department of Pathology,

06110, Diskapi-Ankara

e-mail:scoskan@veterinary.ankara.edu.tr 